\title{
A nursing care plan for Ebola patient at intensive care units
}

\author{
Mary Bi Suh Atanga ${ }^{1}$, Ndipowa James Attangeur ${ }^{2}$ and Kenneth Yongabi Anchang ${ }^{3}$ \\ ${ }^{1}$ Department of Nursing Studies, Faculty of Health Sciences, University of Bamenda, Bamenda, Cameroon. \\ ${ }^{2}$ Department of Nursing, Cameroon Christian University, Bali, Cameroon \\ ${ }^{3}$ Phyto-Biotechnology Research Foundation Institute (PRF), Catholic University of Cameroon, Bamenda, Cameroon
}

Email address:

mbisuh@yahoo.com (M. B. S. Atanga)

\section{To cite this article:}

Mary Bi Suh Atanga, Ndipowa James Attangeur and Kenneth Yongabi Anchang. A Nursing Care Plan for Ebola Patient at Intensive Care Units. American Journal of Clinical and Experimental Medicine. Special Issue: Clinical Innovations, Developments in the Diagnosis, Management and Prevention of Ebola Disease (Marburg fever) and Hemorrhagic Fevers. Vol. 3, No. 1-1, 2015, pp. 14-20. doi: 10.11648/j.ajcem.s.2015030101.13

\begin{abstract}
The state of the art in the nursing care of Ebola hemorrhagic fever in an intensive care was conceived in preparation for nursing especially as Cameroon is found close to West Africa where the dead toll had risen too high in the past several weeks. The objective of this discussion is to outline the steps used from pathophysiology and manifestations of diseases in planning and implementing nursing care for better outcome without contamination of others (nurses themselves inclusive). The search for data was from available literature and nursing techniques. The findings have demonstrated the clear pathophysiology, manifestations, differences between the Marburg haemorrhagic fever and the Ebola, transmission, general management, different levels of care, patients' problems, needs and requirement, nursing care, prevention and strict instructions to be observed. It has provided the basic nursing care plan that could be used in combination with other higher procedures and international norms and standards. The plan can be used by any nurse or delegated persons to ensure safety even when death may be eminent.
\end{abstract}

Keywords: Ebola, Marburg, Patient' S Problems, Nursing Care, Levels of Care

\section{Introduction and Justification}

Nursing has its roots in nurturing and caring; it remains patient-client-centered and results are measured in terms of patient outcome. The role of nursing evolves in response to the needs of society and an expanding body of nursing knowledge (1). From another view point,(2) the unique nurses' function is assisting the individual, sick or well, in the performance of those activities contributing to health or its recovery or to a peaceful death, that he will perform unaided if he had the necessary strength, will, or knowledge.

To achieve the above, a nursing care plan is required but the plan follows the nursing process. It is an essential an important tool in carrying out the tasks roles, and functions of nursing (3). It is a step by step approach to all client/patient care in all conditions. If scrupulously followed in any condition, the client/ patient outcome is most often very appreciable. In the process the second step in planning, where all the client/patient problems are prioritized, and place on the table with clients or patient's (1) or nursing diagnosis (4) as the starting point. The planning phase actually composes of setting priorities, identifying objectives (goals or aims) proposing interventions, weighing alternatives, stating the rational and predicting outcomes. This means that once patient problems (potential and actual) have been identified, priorities are set to provide direction for nursing interventions. The rational is usually the scientific principle (justification or mechanism of action) guiding the action or less the action may be useless or poorly performed (5)

The above is intended to solve problems of all types of client with the ten top conditions in adults now being HIV/AIDS and other infectious diseases, neuropsychiatric conditions, unintentional injuries, cardiovascular diseases, sense organ diseases, intentional injuries, digestive diseases, respiratory diseases, malignant neoplasm.

Among the infectious diseases is Ebola which can occur in epidemic, a great scourge, deadliest, and closely resembles Marburg haemorrhagic fever which must be prevented at all cost BUT health care workers must be prepared to treat and nurse in case of any unexpected ugly circumstances. 
For care in the intensive care to be effective, intensive care arrangements (at level one -district hospital, two- general/ regional hospital, three- specialist hospital), and principles must be taken into serious account. These are found in three levels and nurses' work in all of these levels requiring being abreast with care of Ebola patients when they are called up at any level to do so. Therefore, the levels of care, principles of intensive care for infectious diseases, and the diseases profile, specific nursing care plan, general and preventive nursing need to be addressed even without an outbreak in Cameroon. The overall objective of this write-up is to:To give an overview of the levels of care in intensive care Expose the general principles of intensive care nursing, Discuss the disease in relation to similar diseases,Provide a basic nursing care plan, Provide general and preventive care tips.

Intensive Care units (ICUs) are arranged by singlediscipline like medical ICU, surgical ICU, burn ICU, infectious ICU among others (10). At all times there should be a single entry and exit point, attended by the unit receptionist. Through traffic of goods or staff to other hospital areas must never be allowed. The ICU must have areas for public reception (not in the case of Ebola), patient management and support services which could be divided into: reception area, patient area, storage and utility, technical area, staff area, offices, and other support areas.

The principles of the intensive care unit must include: Supportive intravenous fluids: As nurses work in the intensive care unit they assume many roles as the patients are usually more helpless than other kinds of patients requiring increase fluid intake in the case of Ebola to replace lost fluids and electrolytes in the diarrhea and vomiting. The case of Ebola and Marburg hemorrhagic fevers are worse as the nurses need to battle with prevention of spread to others and protective clothes for them following the loss through these two routes and other secretions. For this to happen. A Strategy for Nursing identified four possible roles for nurses as surrogate parent to these needy near dehydration clients, as technician in the use of all intensive care gadgets, as contracted clinician in making decisions on when fluids are needed, and as advocate for provision of material and equipment necessary in this very important task of intensive in a very contagious disease. Within the ICUs there could conflicts: the technician, the doctors' assistant, the carer for patients over fluid intake. While others deal with technical treatment and maintenance, being the 'prickly' professional nurse work noting all issues of values and beliefs: 'remember our patients are human' (13). This question of values is well illustrated by the semantic dilemma of whether to call the specialty 'Intensive Therapy' (ITU) or 'Intensive Care' (ICU) - in practice, the terms are often interchangeable, and many ICU staff value cure rather than care. Care can (and should) be therapeutic, but therapy (cure) without care is almost a contradiction in terms. Thus, in order to emphasize the caring human role of critical care nurses (and other staff), the art is refers to intensive care in intensive care units (ICUs)'with the use of many technical equipment (technology in practice) to facilitate fluid replacement and other therapies. The other aspect to consider is Technology.

Intensive care is a young specialty but the technology for fast fluid replacement must be considered first in Ebola nursing than the respiratory units for mechanical ventilation which developed from the polio epidemic of 1952-3. These units offered potentially life-saving intervention during acute physiological crises, with the emphasis on medical need and availability of technology. As the technology and medical skills of the specialty developed, so technicians were needed to maintain and operate machines. Although many ICUs employ technicians, technology-related tasks are still delegated to nurses - such as managing bedside machines, recording observations from them and changing regimes as prescriptions change. However, the fact that technology provides a valuable means of monitoring and treatment should not allow it to become a substitute for care as seen below. For nursing to retain a patient-centred focus, it is the patients themselves and not the machines that must remain central to the nurse's role. Therefore, technology should not justify the role or presence of nurses when other manageable materials are available. Healthcare assistants (and, potentially, robots) can be trained to perform technological tasks - and are cheaper to employ than the nurses. While acknowledging the need for technical roles, then, ICU nurses need to be more than just technicians to be able to provide all the care outlined.

Artificial Ventilation is also crucial. Intensive care units developed from respiratory units with the provision of mechanical ventilation and care of ventilated patients, is fundamental to intensive care nursing be it Ebola or other non-communicable conditions. Artificial ventilation should meet physiological deficits (metabolic oxygen demand and carbon dioxide elimination). Early positive pressure ventilators were simple and basic, driven by gas or electrical bellows, delivering gas at a set rate (time), volume or pressure and so ventilators were classified as: time cycled, volume cycled, pressure cycled. Ventilated patients have respiratory failure, so ventilator failure or disconnection may be fatal. Modern ventilators include alarms and default settings, but each nurse should check, and where appropriate reset, alarm limits for each patient and some authors recommend a 'rule of thumb' margin of 10 per cent for alarm settings.

\section{Airway Management Plan for Ebola Patients in Intensive Care}

Another consideration is airway management. Most patients admitted to ICUs receive ventilator support, normally necessitating endotracheal tubes (ETTs) or tracheostomies. ICU nurses are therefore responsible for ensuring patency of, and minimizing complications from, endotracheal tubes (intubations).Traditionally intubation could be: oral, nasal, tracheostomy .Pain management in Ebola infected patients is worth considering. Pain is a response to stimuli which can be physical or psychogenic. 
How the stimuli are perceived by the cerebral cortex determines whether pain exists and, if so, its type and intensity ('quality') must be assessed. The pain in Ebola is from the abdomen and chest as seen in symptoms. If signals are blocked, pain cannot be sensed. Pain is therefore necessarily individual to each sufferer, a complex interaction between physiology and psychology. The individuality of pain experiences underlies widely quoted definition as: 'pain is whatever the experiencing person says it is, existing whenever the experiencing person says it does'. Pain relief can therefore block either reception or perception of pain signals.

However some patients may deny pain, even if experiencing it (possibly due to social expectations-'stiff upper lip'). Nurses should not accept denial of pain, but explore reasons for that denial. Assessing pain, perceptions and needs can be difficult with most ICU patients due to intubation, sedation and/or impaired psychomotor skills, but pain relief and the provision of comfort are fundamental to nursing. Pain has been described in terms of 'hurt' and 'tissue damage', but 'hurt' merely replaces one word by another without clarifying concepts. Pain as a signal of tissue damage (defense mechanism) also ignores psychological stressors, individual interpretations, or powerlessness to prevent tissue degeneration causing chronic pain like in arthritis or other pathologies. Temperature control is a strong indicator to manage.

\section{How Nurses can Manage Pyrexia in Intensive Care}

Nurses treat pyrexia immediately, regardless of causes or severity. Pyrexia (fever) is a homeostatic elevation of body temperature which may be problematic. Heat is produced through metabolism (especially hepatic). Human bodies can only function healthily within a narrow temperature range. The thermoregulatory centre (anterior hypothalamus) responds to central and peripheral thermoreceptors to conserve heat (vasoconstriction) and increase heat production (shivering) when cold and heat loss when hot (sweating, vasodilatation). The thermoregulatory set point varies between individuals, but in health maintains body temperature, usually at $36-37^{\circ} \mathrm{C}$ ). Pyrogens (e.g. TNF $\alpha$, interleukin-1) increase the thermoregulatory set point (usually peaking at $40.5^{\circ} \mathrm{C}$ ), initiating heat production to achieve the higher level (fever). Hypermetabolism to produce heat increases oxygen consumption. Despite being pyrexial, the person feels cold, so attempts to keep warm like extra bedding/clothing. Heat damages living tissue; as most bacteria and viruses are more susceptible to heat than human cells, pyrexia can be a defense mechanism so that temperatures up to $40^{\circ} \mathrm{C}$ may be best untreated. The management of pyrexia should be guided by individual assessment rather than rigid protocols. Hyperpyrexia (heatstroke; above $40^{\circ} \mathrm{C}$ ) damages human cells and so should be treated before reaching the limits of life (at about 43 $44^{\circ} \mathrm{C}$ ). Circadian rhythm causes metabolism and temperature to peak at around 6 p.m. (making this the most suitable time to detect pyrexia, although normal fluctuations rarely exceed $1^{\circ} \mathrm{C}$ over the course of a day. Three stages of febrile response have been described t: (a) chill phase: discrepancy between existing body temperature and the new hypothalamic set point; the person feels cold, shivering to increase hypermetabolism; (b) plateau: temperature overshoots the new set point, triggering heat loss mechanisms; endogenous pyrogen levels also start to fall; (c) diaphoresis and flushing: heat loss through evaporation, with massive reduction in endogenous pyrogen levels, which causes uneven resolution of pyrexia. Fever is a symptom, not a disease; attempts to cool patients, whether by reducing bedding or through active interventions such as tepid sponging, may stimulate further hypothalamus-mediated heat production and so become selfdefeating. Shivering increases metabolism three- to five fold, consuming oxygen and nutrients needed for tissue repair, while increasing carbon dioxide production. Since many ICU patients are already hypoxic, compounding hypoxia by peripheral cooling may prolong recovery. Some disease processes like immunocompromise and treatments like chemotherapy inhibit fever, while artificial cooling may mask clues for diagnosis. Thus the patient, rather than the thermometer, should be treated.

Nutrition benefits from multidisciplinary team approaches are the best; bedside nurses can usefully coordinate care and try to understand that enterai feeding is usually preferable; if nasogastric feeding fails, lower gastrointestinal tubes should be considered; feed regimes should be individually assessed; feed regimes should be fully completed, benefits and problems being monitored; diarrhoea is rarely caused by nasogastric feeding, so is not an indication to stop feeds. Fluids and feeds are needed in the nursing of Ebola and Marburg fevers and fluid loss via diarrhea and vomiting are replaced.Oral ill-health has significant short-term and longterm effects. Oral hygiene facilitates: comfort; sensory balance and prevention of infection. Patients in ICU often develop dry mouths (xerostomia) from absence of oral intake; adverse effects of therapeutic drugs (like morphine, diuretics, tranquillizers and antibiotics; sympathetic nervous system stimulation (reduces salivary secretion) causes poor salivary production and drying (convection) from mouths wedged open by oral endotracheal tubes. The moistening of patients' mouths provides comfort, but it also reduces the oral stasis which, together with immunosuppression, exposes them to potential oral infection. Plaque formation can occur rapidly; survivors of ICU may subsequently suffer tooth loss from plaque damage. Oral hygiene also contributes to psychological comfort. The mouth is used to communicate. Lip-reading is possible despite intubation, and following extubation, oral discomfort may make speech difficult. The mouth is also associated with intimate emotions (smiling, kissing); patients with, or thinking they have, dirty mouths or halitosis may feel psychologically isolated. The provision of oral hygiene merely replaces activities ICU patients would normally perform for themselves, if able. Mouth care should 
therefore constant and so to maintain hygiene: keep the oral cavity moist; promote comfort; protect from infection; prevent trauma; prevent dental decay by twice daily cleansing and after each episode of vomiting when there is vomiting.Eye care in ICUs often suffers from the vagaries of ritual, priorities and knowledge, and receives scant attention in the nursing literature, so that ICU nurses have little evidence beyond scattered anecdotes to guide practice. Some of the risks ICU patients' eyes are exposed to, and some approaches to care from the little specialist literature are provided. However, suggestions necessarily remain tentative, substantial research being needed to develop evidence-based practice. Eye care is important for both physiological and psychological reasons. Eye contact helps communication; nurses may feel squeamish about touching eyes, but ocular abnormalities often provoke anxiety among patients and relatives. Vision is, for most people, the most used sense, and so visual deficits contribute significantly to sensory imbalance. Therefore, ICU nurses should evaluate; the eye care performed and visual appearance checked with twice daily cleansing. While assessing and caring for a patient's eyes, nurses can also make neurological assessment of pupil size and reaction, accommodation for near and long vision (assessed by placing a finger near the patient's nose and moving the finger away causes pupils to diverge). Ocular damage may invalidate any or all of these tests and aid called in.

Despite the high profile of wound and pressure area care, skincare remains problematic in ICUs with many patients developing sores. Traditionally, pressure sores were equated with bad nursing, and this created a culture of guilt and denial in nursing. Most ICU patients are exposed to high risk of skin breakdown from: prolonged peripheral hypoperfusion; oedematous tissue; anaerobic metabolism; immunocompromise; malnutrition and weakness of tissues from the Ebola infection Injury can be through disease or treatments like surgical incision, invasive equipment or lying down for too long. Since the skin is renewed every 28 days healing is prolonged compared to most ICU admissions. The high ICU nurse-patient ratios should facilitate individualised assessment and care to prevent breakdown and minimize complications. A pressure Sore is localised tissue necrosis resulting from prolonged lying down, evasive interventions or rumpled bed linen. Forty per cent of American ICU patients develop pressure sores (16); in the UK the incidence is probably higher due to the higher dependency of ICU patients here. Pressure sores can be caused by both extrinsic factors like unrelieved pressure; shearing; friction, and intrinsic factors; age; malnutrition; dehydration; incontinence; medical condition; medication. The supply of tissue oxygen and nutrients and the removal of waste products of metabolism require capillary perfusion; initial damage causes cellular micro- trauma, and so supporting microcirculation and the provision of adequate nutrition are fundamental to pressure sore prevention. Capillary perfusion depends on various forces including external pressure. The pressure needed to prevent capillary flow is called capillary occlusion pressure.

Sensory balance and psychological health are threatened by exogenous (for example environmental) and endogenous (for example body rhythms) factors. Sensory imbalance includes overload and deprivation, although literature may use other names (ICU syndrome, ICU psychosis/delirium, sleep disturbance/deprivation). Confusion may have many causes: sensory imbalance, acute cerebral hypoxia/ischaemia/damage, and chronic cerebral damage. Most touch in ICU remains task-orientated which is not too good for patients in the ICU. Task-orientated touch is necessary, but reduces individuals to commodities, reinforcing their dehumanization. Patients appreciate having their pillows turned and their head stroked in a comforting manner (affective touch). This touch cannot be with direct contact to the patient in the case of Ebola and Marburg fevers but attempts should be made to touch even with protective dressing hindering direct touch which seems task-orientated. Following the diarrhea in Ebola heamorrhagic fever, the anal region requires constant care. This care should be moist cleansing with emulsifying scream applied after that to avoid skin excoriations.

The increasing emphasis by the nursing profession on psychology and the psychological needs of patients, whether conscious or unconscious, makes psychological care an essential part of holistic care-a focus noticeably absent in the medical and technological perspectives of care. Most ICU nurses are more concerned with the psychosocial stressors, while patients are more concerned with their physical care. Patients' needs and nursing care vary between units and individuals, but, if the foregoing is right, there is cognitive dissonance between ICU nurses and their patients. Since patients are admitted to ICU with acute physiological crises, intervention must necessarily focus care on their physical needs-for instance the fluid needs of the ICU patients. More is needed in their care rather than ritualistically following lists of pre-ordained cues (like assessment forms), nurses should actively evaluate the holistic needs of their patients; by acknowledging these individual psychological needs. ICU nurses can complement the valuable physiological care offered by the other professions but the psychological lies exclusively in their hands. In recognising both the physical and psychological needs of patients, nurses can add a humane, holistic perspective into the care, preparing their patients for recovery and discharge amidst the troubles of Ebola. The intrinsic needs of patients derive from their own physiological deficits, including many 'activities of living' (like communication, comfort, freedom from pain); meeting these needs is fundamental to nursing, and this provides the focus of nursing in ICU. People are influenced by, and interact with, their environment; their extrinsic needs, which define each person as a unique individual, rather than just a biologically functioning organism. These aspects include: dignity, privacy, psychological support, and spiritual support.

Generally, the nursing care in ICU is concerned with provision of life support, monitoring critical illness in patients and their response to interventions, and prevention of 
complications, particularly prevention of nosocomial infections as they are very common in ebola. It is also concerned with patient comfort, understanding and family information, understanding and support (11). Very important in the deadliest disease is that there must be prevention which must include the total population through mass health education as below. This must include involvement and recognition of communities and total population as critical role players in management (12) using the four Ps as below The art of prevention in Ebola is the duty of all "task for all"health personnel, government, communities, individuals, families and various groups. Presently in Cameroon, government has put all efforts to prevent by health education to the general public, intensify quarantine, and reinforce health workforce capacity, provision of equipment and material and general financial preparedness in conjunction with international organizations like the World Health Organization. Due to the highly nature of the contamination of the disease, the personnel and every other treating or organizing individual must be dressed properly in protective clothing already mentioned.

Table 1. Nursing care plan for $M r X$, bed number $x x$, time $x x$, date $x x$

\begin{tabular}{|c|c|c|c|c|c|}
\hline S/N & Client's problem & Objective & Intervention & Rational & Expected outcome \\
\hline 1 & Fever & $\begin{array}{l}\text { To reduce temperature } \\
\text { within the first } 30 \mathrm{~min}\end{array}$ & Tepid sponge & $\begin{array}{l}\text { Cools body surface, } \\
\text { exposes spores. }\end{array}$ & $\begin{array}{l}\text { Internal heat is displaced by } \\
\text { vaporization via the cooled } \\
\text { skin surface }\end{array}$ \\
\hline 2 & Headache & $\begin{array}{l}\text { To reduce headache } \\
\text { within first } 30 \mathrm{~min} .\end{array}$ & $\begin{array}{l}\text { Serve analgesics. Apply } \\
\text { warm compress. Position } \\
\text { head on pillow }\end{array}$ & $\begin{array}{l}\text { Block pain receptors. } \\
\text { Increases blood flow for } \\
\text { circulation. Reduces } \\
\text { intracranial pressure }\end{array}$ & $\begin{array}{l}\text { Patient expresses relief of } \\
\text { headache. }\end{array}$ \\
\hline 3 & Joint /muscle pain & $\begin{array}{l}\text { To reduce pain all } \\
\text { through }\end{array}$ & $\begin{array}{l}\text { Serve muscle relaxant. } \\
\text { Apply gentle massage }\end{array}$ & $\begin{array}{l}\text { Relaxants relief pain by } \\
\text { their smoothing effects. } \\
\text { Massage encourages } \\
\text { vasodilatation for inflow } \\
\text { of macrophages }\end{array}$ & $\begin{array}{l}\text { Patient expresses relief on a } \\
\text { daily basis all through care } \\
\text { period }\end{array}$ \\
\hline 4 & Diarrhoea & $\begin{array}{l}\text { To reduce bowel } \\
\text { movements with the } \\
\text { first } 30 \mathrm{~min}\end{array}$ & $\begin{array}{l}\text { Serve cold drink with } \\
\text { antacids and } \\
\text { antispasmodic }\end{array}$ & $\begin{array}{l}\text { Constrict blood vessels } \\
\text { reducing blood flow that } \\
\text { may irritate intestinal } \\
\text { lining. Coats lining. } \\
\text { Reduces peristalsis }\end{array}$ & \\
\hline 5 & Vomiting & $\begin{array}{l}\text { To relief patient of } \\
\text { vomiting within } 30 \\
\text { min. }\end{array}$ & $\begin{array}{l}\text { Serve anti-emetics. } \\
\text { Compress diaphragm }\end{array}$ & $\begin{array}{l}\text { Relaxes the vagus nerve } \\
\text { endings reducing irritation. } \\
\text { Reduces backward } \\
\text { movement of stomach } \\
\text { contents }\end{array}$ & $\begin{array}{l}\text { Vomiting episodes reduced } \\
\text { within the first } 30 \text { minutes of } \\
\text { nursing care }\end{array}$ \\
\hline 6 & Stomach pain & $\begin{array}{l}\text { To reduce abdominal } \\
\text { pains within the first } \\
30 \mathrm{~min}\end{array}$ & $\begin{array}{l}\text { Serve warm water to } \\
\text { drink. Serve antacids. } \\
\text { Serve anti-spasmodic }\end{array}$ & $\begin{array}{l}\text { Encourages increase blood } \\
\text { flow with microphages to } \\
\text { stomach. Coat stomach } \\
\text { lining. Reduce peristaltic } \\
\text { movements }\end{array}$ & $\begin{array}{l}\text { Patient expresses relief } \\
\text { within } 30 \text { minutes of nursing } \\
\text { care }\end{array}$ \\
\hline 7 & Skin rash & $\begin{array}{l}\text { To reduce rash and } \\
\text { prevent sores all } \\
\text { through } \\
\text { hospitalization }\end{array}$ & $\begin{array}{l}\text { Assisting BD baths. } \\
\text { Application anti-pruritic } \\
\text { agents. Frequent change } \\
\text { of position }\end{array}$ & $\begin{array}{l}\text { Clears skin of discharges } \\
\text { from rash \& prevent } \\
\text { further spread. Stops } \\
\text { itching prevent } \\
\text { excoriations from } \\
\text { scratching. Encourages } \\
\text { circulation }\end{array}$ & $\begin{array}{l}\text { Body is gradually cleared of } \\
\text { rash as itching is prevented. } \\
\text { No bedsores following } \\
\text { change of positions and free } \\
\text { circulation of blood }\end{array}$ \\
\hline 8 & Discharging eyes & $\begin{array}{l}\text { To clear eyes of } \\
\text { discharges PRN }\end{array}$ & $\begin{array}{l}\text { Cleanse with cleansing } \\
\text { lotion regularly }\end{array}$ & $\begin{array}{l}\text { Relieves the discharge, } \\
\text { enhancing opening of eyes }\end{array}$ & $\begin{array}{l}\text { Eyes open and see well after } \\
\text { each cleansing }\end{array}$ \\
\hline 9 & Hiccups & $\begin{array}{l}\text { To stop the hiccup in } \\
\text { the first } 30 \mathrm{~min} .\end{array}$ & $\begin{array}{l}\text { Apply warm compress on } \\
\text { the diaphragm. Serve } \\
\text { warm drink }\end{array}$ & $\begin{array}{l}\text { Increase blood supply by } \\
\text { vasodilatation for inflow } \\
\text { of body defences }\end{array}$ & $\begin{array}{l}\text { Hiccups disappear within the } \\
\text { first } 30 \text { min. of nursing care }\end{array}$ \\
\hline 10 & $\begin{array}{l}\text { Internal and/or external } \\
\text { bleeding }\end{array}$ & $\begin{array}{l}\text { To reduce bleeding } \\
\text { within the first day of } \\
\text { nursing }\end{array}$ & Apply ice packs or soaks & Constrict blood vessels & $\begin{array}{l}\text { Bleeding is reduced within } \\
\text { the first day of nursing }\end{array}$ \\
\hline 11 & Dehydration & $\begin{array}{l}\text { To replaced lost fluids } \\
\text { with the first } 30 \\
\text { minutes of nursing }\end{array}$ & Place intravenous fluids & $\begin{array}{l}\text { Promotes homeostasis by - } \\
\text {-- }\end{array}$ & $\begin{array}{l}\text { Skin tugor of patient de is } \\
\text { firm demonstrating control of } \\
\text { dehydration }\end{array}$ \\
\hline 12 & Sore throat & $\begin{array}{l}\text { Thin first one hour of } \\
\text { care }\end{array}$ & $\begin{array}{l}\text { Serve lozenges and } \\
\text { antibiotics }\end{array}$ & $\begin{array}{l}\text { Emulsifies mucus } \\
\text { membrane lining, } \\
\text { eliminates microb }\end{array}$ & $\begin{array}{l}\text { Patients expresses the } \\
\text { disappearance of sore within- } \\
\text {---- }\end{array}$ \\
\hline 13 & Chest pain & $\begin{array}{l}\text { To reduce chest pain } \\
\text { in the first } 30 \mathrm{~min} .\end{array}$ & $\begin{array}{l}\text { Fowler's position. } \\
\text { Warmth to chest }\end{array}$ & $\begin{array}{l}\text { Encourages abdominal and } \\
\text { chest organs and structures } \\
\text { to be maintained in their }\end{array}$ & $\begin{array}{l}\text { Patients expresses relief } \\
\text { within the first } 30 \text { min. of } \\
\text { nursing care }\end{array}$ \\
\hline
\end{tabular}




\begin{tabular}{|c|c|c|c|c|c|}
\hline $\mathbf{S} / \mathbf{N}$ & Client's problem & Objective & Intervention & Rational & Expected outcome \\
\hline & & & & normal positions & \\
\hline 14 & Delirium & $\begin{array}{l}\text { To reduce delirious } \\
\text { state all through } \\
\text { period of } \\
\text { hospitalization }\end{array}$ & $\begin{array}{l}\text { Constant touch, } \\
\text { conversation and change } \\
\text { of position }\end{array}$ & $\begin{array}{l}\text { Stimulates sensory } \\
\text { responses }\end{array}$ & $\begin{array}{l}\text { Patient reacts to touch, feels } \\
\text { sensations all through period } \\
\text { of hospitalization }\end{array}$ \\
\hline 15 & Viral spread & $\begin{array}{l}\text { To stop any form of } \\
\text { contamination all } \\
\text { through }\end{array}$ & $\begin{array}{l}\text { Proper hand washing } \\
\text { even with protection. } \\
\text { Sterile protective clothes. } \\
\text { Proper disposal of used } \\
\text { materials }\end{array}$ & $\begin{array}{l}\text { Kills all micro-organisms } \\
\text { or stops replication and } \\
\text { multiplication }\end{array}$ & $\begin{array}{l}\text { All surfaces and materials are } \\
\text { free of pathogens all through }\end{array}$ \\
\hline 16 & $\begin{array}{l}\text { Potential for nosocomial } \\
\text { infection. }\end{array}$ & $\begin{array}{l}\text { To stop any form of } \\
\text { hospital acquired } \\
\text { infection all through. }\end{array}$ & $\begin{array}{l}\text { Observe \& maintain } \\
\text { isolation roles. Check for } \\
\text { any incubating illnesses }\end{array}$ & $\begin{array}{l}\text { No source of } \\
\text { contamination is present. } \\
\text { Ascertains the non } \\
\text { presence of an incubating } \\
\text { illn }\end{array}$ & $\begin{array}{l}\text { Patient leaves hospital with } \\
\text { no new infection. }\end{array}$ \\
\hline 17 & $\begin{array}{l}\text { Deficit knowledge of the } \\
\text { disease }\end{array}$ & $\begin{array}{l}\text { To inform patient on } \\
\text { the cause and } \\
\text { prevention }\end{array}$ & $\begin{array}{l}\text { Outline the disease, } \\
\text { cause and prevention }\end{array}$ & $\begin{array}{l}\text { Instills an element of } \\
\text { comprehension of the } \\
\text { disease }\end{array}$ & $\begin{array}{l}\text { Patient narrates the disease, } \\
\text { causes and prevention on } \\
\text { discharge }\end{array}$ \\
\hline
\end{tabular}

This plan is just a demonstration with basic nursing tasks only. There is much more to be done for each of the problems.

General Nursing Care

- Strict infection control

- Strict isolation

- Strict asepsis

- Protective clothes

- No direct contact with patient

- Application of intensive care principles

- Disinfection \& disposal of all used materials

- Strict disposal of the dead

Preventive Nursing

- Education on healthy lifestyles

- Balanced and well cooked food

- Reduce or no alcohol

- No cigarette smoking

- No playing with monkeys

- No eating of bush meat

- Regular exercise

- Appropriate sewage disposal

- Good personal hygiene

- No eating of plumes eaten by bats (wounded fruits)

\section{Conclusion}

The nursing care plan for Ebola viral patients at intensive care unit has been presented not as an invitation for the disease but as an alert to the kinds of things and issues that should be addressed in an event where a nurse is faced with the care of such patients. The state of nursing, obligations, tasks, duties and functions have been enumerated. A close look at the principles of intensive provided are meant to give some clues to what must be remembered in case of an Ebola outbreak with ICU needed. The disease Ebola has also been compared with Marburg as no disease is said to be particular to a particular region. Movement from place to place by humans has not been stopped so are diseases. A sample or miniature nursing care plan has been presented to show the problems the patients may face and the possible actions to be taken (not exhaustive). Many actions are taken for each problem which have not all been presented. In the same way, the problems are not exhaustive. Tips to general and preventive nursing have also been provided to reinforce the public health measures used.

\section{Recommendations}

1. Continuous and strict prevention must be maintained

2. Each patient must be considered as an individual requiring a specific nursing care plan at any one point in time.

3. The level of the intensive must at tertiary level with strict isolation roles.

\section{References}

[1] Watson, J.E. Medical-Surgical Nursing and Related Physiology. $3^{\text {rd }}$ Ed. Richard Clay Ltd Salfolk, England. 1990.

[2] Henderson, V. 'Preserving the essence of nursing in a technological age', Journal of Advanced Nursing 5(3): 24560.1980

[3] Atanga, M.B.S.\& Uys R.L. The Role of the Nurse in Cameroon Health Services. African Journal of Socila Sciences. A multidisciplinary Journal of Social Sciences. Vol. 3. No. 4 (Special Edition). Pp 41-53. 2012

[4] Kozier, B.\& Erb, G. Fundamentals of Nursing. Concepts and Procedures. $3^{\text {rd }}$ Ed. Addison-Wesley Pub Co, California pp 209-298. 1987

[5] Elhart, D; Firsich, S.C; Gragg, S.H. \& Rees, O.M. Scientific Principles in Nursing. $8^{\text {th }}$ Ed with 141 illustrations. The C.V mosby Company, saint Lousi. 1978

[6] World Health Organization-WHO. The Global Burden of Disease; 2004 Update. Geneva. WHO. www.who.in.evidence/bod. 2008.

[7] Atanga, M.B.S. \& Uys, R.L. The Case Study of Some Cameroonian Health -Related Indicators: A Focus on Nursing. African journal of Social Sciences: A multidisciplinary Journal of Social Sciences. Vol 3 No. 3 pp 58-70. 2012

[8] National Institute of Health and Infectious Diseases. UK. 2014 
[9] Birnso, O. The Ebola Disease. Communication from a Toxicological view point. 2014

[10] Oh, T.E. Designing and Organization of Intensive Care Units. Intensive Care Manual. $4^{\text {th }}$ Ed. pp 1-16. 1998

[11] McKinley, S. Critical Care Nursing. Intensive Care Manual. $4^{\text {th }}$ Ed. Pp 33-39. 1998

[12] Atanga, M.B.S. \& Merwe, A.V.D. A Community Health Model to Manage Health Hazards. LAP LAMBERT Academic Publishing, Saarbrucken, Deutschland/Germany. ISBN 978-3659- 28026-9 pp 69-90. 2012
[13] Woodraw, P. Intensive Care Nursing: A Framework for Practice. Clinical Scenarios by Jane Roe. Routledge, London. 2000

[14] Hudak, C.M., Gallo, B.M. and Morton, P.G. (eds) Critical Care Nursing: A Holistic Approach , 7th edn, Philadelphia: Lippincott.1998

[15] Adam, S.K. and Osborne, C. Critical Care Nursing: Science and Practice, Oxford: Oxford Medical Publications. 1997

[16] Westrate, J.M.T. and Bruining, H.A. 'Pressure sores in an intensive care unit and related variables: a descriptive study', Intensive and Critical Care Nursing 12(5): 280-4. 1996 